\section{Cover Crops Resistant to Root-lesion Nematodes in Raspberry}

\author{
Thierry Vrain, Robyn DeYoung, and John Hall \\ Agriculture and Agri-Food Canada, Pacific Agri-Food Research Centre, \\ Summerland, B.C. VOH 1Z0, Canada
}

\author{
Stan Freyman \\ Agriculture and Agri-Food Canada, Pacific Agriculture Research Centre, \\ P.O. Box 1000, Agassiz, B.C. V0M 1A0, Canada
}

Additional index words. resistance, suppressive crops, competition

\begin{abstract}
Cover crops used in red raspberry plantings (Rubus idaeus L.) are often good hosts of the root-lesion nematode (Pratylenchus penetrans Filipjev \& Sch. Stekoven), a major soilborne pathogen of raspberry. The effects of two susceptible cover crops, white clover (Trifolium repens $\mathbf{L}$.) and barley (Hordeum vulgare $\mathbf{L}$.), planted in between rows, on nematode density and growth of raspberry plants were compared to those of three cover crops resistant to the nematode: redtop (Agrostis alba $\mathbf{L}$.), creeping red fescue (Festuca rubra $\mathrm{L}$.), and 'Saia' oat (Avena sativa $\mathrm{L}$.). Nematode multiplication in raspberry roots and in cover crop roots was assessed over 4 years. Growth and vigor of plants were estimated at the end of the experiment by counting primocanes and determining height and biomass. Nematode multiplication was suppressed in roots of 'Saia' oat, fescue, and redtop compared to barley or white clover. Nematode density in roots and rhizosphere soil of raspberry was not affected by the choice of cover crops. Nematode suppression in the three resistant cover crops did not translate into increased vigor of raspberry plants.
\end{abstract}

Cover crops are used in red raspberry plantings to minimize soil erosion, reduce competition from weeds and the need for weed control, increase soil organic matter, and provide a habitat for beneficial arthropods. However, permanent covers can also compete with the raspberry plants for soil water and nutrients and subsequently reduce yields (Allott, 1970; Catzeflis et al., 1987). Chamberlain and Crandall (1979) observed that a cover of red fescue or ryegrass (Lolium perenne L. cv. Manhattan) between raspberry rows caused a decrease in cane growth and fruit yield one year but not the next, after irrigation and fertilization regimes were adjusted to compensate for competition from the cover crop. Sanderson and Cutcliffe (1988) found that a continuous grass sod lowered raspberry yields by $25 \%$ when compared to soil cultivation, whereas cultivation until harvest and then planting oats did not lower yields.

The root-lesion nematode is a soilborne pest of raspberry plantings in the Pacific Northwest and most other producing regions (McElroy, 1972; Vrain et al., 1994, 1996). Raspberry transplants are so susceptible to this nematode that infested fields must be fumigated before planting (McElroy, 1977). The host status of cover crops for the rootlesion nematode has been assessed in greenhouse (Dunn and Mai, 1973; Ingham and Kaufman, 1992; Townshend, 1989; Townshend and Potter, 1976) and field experi-

Received for publication 29 Apr. 1996. Accepted for publication 28 July 1996 . The cost of publishing this paper was defrayed in part by the payment of page charges. Under postal regulations, this paper therefore must be hereby marked advertisement solely to indicate this fact. ments involving apple (Malus domestica Borkh.) (MacDonald and Mai, 1963; Marks and Townshend, 1973; Merwin and Stiles, 1989) and raspberry (Edwards et al. 1994; Townshend et al., 1984). These earlier studies did not always specify the cultivar of cover crop tested, but it has recently been shown that grain crops like oat or rye (Secale cereale L.), which are normally excellent hosts for this nematode, have some resistant cultivars that restrict multiplication of the nematode (Kaufman, 1995; Townshend, 1989). Most of these studies determined whether particular cover crops could be used to reduce nematode density in soil before planting a susceptible crop. These earlier studies also did not consider the effects of cover crops planted between rows of an established perennial crop. Furthermore, it was not determined whether changes in crop growth were the indirect result of changes in nematode parasitism or the direct result of competition with the cover crop for water and nutrients.

Barley is traditionally used as a temporary cover crop in raspberry plantings in British Columbia, mostly to prevent soil erosion and increase soil organic matter content. It is planted between raspberry rows in August, immediately after fruit harvest, and grows in late summer and fall. The barley plants are killed during the winter and the remains are left as mulch or are disked under in the spring. Unfortunately, barley is a very good host of the rootlesion nematode, which multiplies to high densities in the roots. Since barley promotes nematode multiplication in the proximity of raspberry roots, its use as a cover crop could increase parasitic pressure by the nematode on the raspberry plants, thereby decreasing vigor and lowering fruit yield.
The objective of this study was to determine whether cover crops other than barley could be used advantageously between rows of raspberries. The cover crops chosen showed a distinct advantage in previous studies. Redtop, creeping red fescue, and 'Saia' oat all had suppressed nematode multiplication(Edwards et al., 1994; Townshend, 1989), while white clover, although a good host of the nematode, had increased raspberry yields (Bowen and Freyman, 1995; Freyman, 1989). The direct effects of the cover crops on raspberry growth and vigor, and indirect effects through nematode suppression, were compared to those of barley.

\section{Materials and Methods}

A 4-year experiment was set up at the Abbotsford (British Columbia) experimental farm of the Pacific Agriculture Research Centre of Agriculture and Agri-Food Canada. The design was a randomized complete block with six treatments (five cover crops plus a control) in each of five blocks. Each cover crop plot (9 $\times 6 \mathrm{~m})$ had a row of 'Willamette' raspberry in the middle, bordered by a guard row of 'Willamette' raspberry on each side, for a total of 13 rows per block. Each row consisted of 18 plants $50 \mathrm{~cm}$ apart planted in a $40-\mathrm{cm}$-wide strip left clear of any cover when the experiment was established (28 Mar. 1990).

Cover crops were seeded (28 Mar. 1990) as a solid planting $(9 \times 2.60 \mathrm{~m})$ on each side of the center row of raspberry. The cover crops were: 'Canada \#1' redtop; 'Roland 21' creeping red fescue; 'Saia' oats; 'Galt' barley; and 'New Zealand Dwarf' white clover. The control plots had no ground cover, and were rotovated as necessary to prevent excessive weed growth. The soil was a well-drained sandy loam with $7.5 \%$ organic matter, $\mathrm{pH} 5.3$ to 5.7 , infested with root-lesion nematodes. Cultivation, thinning, pruning and training of raspberry canes, fertilization, and disease and insect control measures were uniformly applied, when required, according to local recommendations (British Columbia Ministry of Agriculture, 1992). Weeds were controlled as necessary by hand and hoe weeding.

Nematode density (number $/ 50 \mathrm{~mL}$ soil) in each plot was determined 3 weeks before planting to ensure that there were no significant differences in initial nematode densities between plots. Densities in rhizosphere soil and root samples of each cover crop and of the raspberry plants were determined by sampling the central eight plants of each plot and adjacent covers during the next 3 years: 28 Nov. 1990; 10 Apr., 6 Aug., and 26 Nov. 1991; 17 Mar. and 3 Nov. 1992; and lastly on 12 May 1993. Ten cores of soil ( $2 \mathrm{~cm}$ in diameter) were taken to $25 \mathrm{~cm}$ deep in each raspberry row,

Table 1. Analysis of variance of $\log _{10}$ transformed root-lesion nematode densities in soil before treatment (Mar. 1990).

\begin{tabular}{lrc}
\hline \hline Source of variation & df & Mean square \\
\hline Future cover crop & 5 & 0.0079 \\
Block & 4 & 0.0200 \\
Error & 20 & 0.0169 \\
\hline
\end{tabular}


within $20 \mathrm{~cm}$ of the center of rows, and in each adjacent cover crop. Pieces of roots in each soil sample were washed of soil and weighed. Nematodes were extracted from each root fraction for 7 days in a misting chamber at 25 ${ }^{\circ} \mathrm{C}$ (Seinhorst, 1956), and extracted from 50 $\mathrm{mL}$ of soil of each sample in Baermann pans for 7 days (Townshend, 1963).

Nematode counts were transformed to $\log _{10}$ $(\mathrm{x}+100)$ before analysis of variance (ANOVA) to correct for heterogeneity of variance (Proctor and Marks, 1974). Nematode counts measured in the soil in Mar. 1990, before treatment, were tested by ANOVA to ensure that there were no pretreatment differences. The effect of the cover crops on nematode densities in soil and roots were tested by ANOVA with the eight dates of sampling as repeated measures. The F tests for the sources of variation involving dates were corrected using the Greenhouse-Geisser adjustment (Littell, 1989). Biomass of raspberry primocanes was measured 7-8 Mar. 1994. The number of primocanes per plant, height of each cane, diameter at $50 \mathrm{~cm}$ height, and weight of each cane were recorded. The effects of the cover crops on the raspberry cane variables were tested by ANOVA. Correlations were calculated among the log-transformed nematode densities separately for the three spring (Mar. 1991, Mar. 1992, May 1993) and the three fall samples (Nov. 1990 through 1992) because relationships may differ at the two seasons of the year. Correlations also were calculated between the log-transformed nematode densities in May 1993 and the raspberry fruiting cane variables measured in Mar. 1994.

\section{Results and Discussion}

There were no significant differences in nematode density in soil among plots before seeding in Mar. 1990 (Table 1). The use of resistant cover crops had no significant impact on the nematode density in roots and rhizosphere of adjacent raspberry plants (Tables 2 and 3). The nematode densities in cover crop soil and roots varied among cover crop species (Table 2). 'Saia' oats, creeping red fescue, and redtop usually supported a fraction of the nematode densities found in barley roots and rhizosphere soil. These differences changed detectably with time, i.e., there were cover crop $\times$ time interactions (Table 3 ). Weeds were not completely controlled in the control plots and the root-lesion nematode multiplied to extremely high counts on certain weed species. Correlations among nematode densities in soil or roots of cover crops and of raspberries in the spring or the fall sampling were calculated. Many such correlations were significant, more so in the fall than in the spring, during the 4 years of the study (Table 4).

Our finding confirms previous observations (Powlowski, 1991), where a nematode population having reached equilibrium in roots and rhizosphere soil of a perennial crop was not necessarily influenced by a nematode suppressive cover crop. Marigolds (Tagetes patula L.) nearly eradicated root-lesion nematodes from infested apple orchard soil, but they had no significant effects on nematode density in roots of established young trees (unpublished data).

Yield of raspberries is determined by the vigor and health status of the plants in the previous year. Growth measurements taken in Mar. 1994 on primocanes likely reflect parasitic pressure on the raspberry plants in 1993. Measurement of height and diameter of canes gives a good estimate of yield, since cane height is correlated with cane diameter and both are correlated with yield (Crandall et al., 1974). There were detectable differences among cover crops in total mass but not in total number of fruiting raspberry canes (Table 5). Fruiting canes tended to be largest with the control cover and smallest with the fescue cover as measured by average cane mass, height, and diameter. Given the design of the experiment, it was not possible to determine whether the cover crops affected the raspberry plants directly through allelopathy or competition for soil water and nutrients, or indirectly through increasing or decreasing parasitic pressure from nematodes. Correlations between densities of root-lesion nematodes in May 1993 and raspberry plant variables did not

Table 2. Density of root-lesion nematodes in rhizosphere soil and roots of raspberry and adjacent cover crops at various times during 3 years.

\begin{tabular}{|c|c|c|c|c|c|c|c|c|c|}
\hline \multirow{2}{*}{$\begin{array}{l}\text { Cover crop } \\
\text { and location }\end{array}$} & \multicolumn{9}{|c|}{ Density of root-lesion nematodes (counts) at time indicated } \\
\hline & Mar. 1990 & Nov. 1990 & Apr. 1991 & Aug. 1991 & Nov. 1991 & Mar. 1992 & Nov. 1992 & May 1993 & Mean \\
\hline \multicolumn{10}{|c|}{ Raspberry soil } \\
\hline None & 143 & 1061 & 495 & 1244 & 822 & 861 & 503 & 372 & 765 \\
\hline Barley & 106 & 754 & 491 & 1214 & 824 & 756 & 229 & 287 & 651 \\
\hline White clover & 108 & 616 & 497 & 1471 & 969 & 1013 & 301 & 312 & 740 \\
\hline Oats & 124 & 716 & 847 & 1216 & 919 & 728 & 173 & 290 & 699 \\
\hline Red fescue & 99 & 755 & 483 & 1099 & 778 & 737 & 227 & 246 & 618 \\
\hline Redtop & 73 & 705 & 364 & 1136 & 790 & 937 & 211 & 347 & 642 \\
\hline $\operatorname{RSE}^{y}$ & 0.13 & 0.13 & 0.11 & 0.14 & 0.14 & 0.12 & 0.18 & 0.22 & 0.07 \\
\hline \multicolumn{10}{|c|}{ Raspberry roots ${ }^{x}$} \\
\hline None & & 3618 & 2820 & 3597 & 4009 & 1680 & 1654 & 1434 & 2687 \\
\hline Barley & & 2957 & 3461 & 4515 & 4366 & 1910 & 4164 & 2443 & 3402 \\
\hline White clover & & 4896 & 1737 & 8578 & 4839 & 1934 & 1718 & 1029 & 3533 \\
\hline Oats & & 5253 & 3131 & 3211 & 3248 & 1889 & 1643 & 1557 & 2847 \\
\hline Red fescue & & 15193 & 3344 & 3285 & 1024 & 1609 & 1040 & 1075 & 3796 \\
\hline Redtop & & 3714 & 3657 & 2944 & 5080 & 1612 & 976 & 980 & 2709 \\
\hline $\operatorname{RSE}^{y}$ & & 0.34 & 0.26 & 0.39 & 0.41 & 0.45 & 0.34 & 0.20 & 0.20 \\
\hline \multicolumn{10}{|c|}{ Cover crop soil ${ }^{2}$} \\
\hline None (weeds) & & 344 & 238 & 119 & 171 & 131 & 177 & 153 & 190 \\
\hline Barley & & 333 & 398 & 465 & 228 & 364 & 203 & 437 & 347 \\
\hline White clover & & 1149 & 469 & 1707 & 1349 & 564 & 590 & 456 & 897 \\
\hline Oats & & 57 & 107 & 291 & 104 & 100 & 58 & 135 & 122 \\
\hline Red fescue & & 261 & 163 & 94 & 101 & 93 & 96 & 52 & 123 \\
\hline Redtop & & 149 & 117 & 142 & 201 & 134 & 84 & 66 & 128 \\
\hline $\operatorname{RSE}^{\mathrm{y}}$ & & 0.09 & 0.11 & 0.17 & 0.14 & 0.22 & 0.36 & 0.20 & 0.07 \\
\hline \multicolumn{10}{|c|}{ Cover crop roots ${ }^{x}$} \\
\hline None (weeds) & & 4608 & 59300 & 1492 & 1988 & 2080 & 5537 & 1974 & 15461 \\
\hline Barley & & 4570 & 6886 & 6936 & 4365 & 6799 & 5039 & 8067 & 5988 \\
\hline White clover & & 6432 & 8486 & 2702 & 6282 & 3858 & 3346 & 3913 & 5002 \\
\hline Oats & & 1156 & 1725 & 2465 & 837 & 275 & 762 & 2904 & 1462 \\
\hline Red fescue & & 2391 & 1101 & 164 & 343 & 342 & 358 & 316 & 716 \\
\hline Redtop & & 996 & 460 & 268 & 1038 & 478 & 169 & 157 & 508 \\
\hline $\operatorname{RSE}^{y}$ & & 0.30 & 0.53 & 0.40 & 0.43 & 0.36 & 0.36 & 0.35 & 0.27 \\
\hline
\end{tabular}

${ }^{2}$ Nematode count (all juvenile and adult stages) per $50 \mathrm{~mL}$ of rhizosphere soil.

${ }^{\mathrm{y}}$ Relative standard error (the standard error of a mean is: mean $\times \mathrm{RSE}$ ).

${ }^{\mathrm{x}} \mathrm{Nematode}$ count (all juvenile and adult stages) per gram of fine roots. 
point to an effect of the nematodes in cover crop roots or soil on the growth of the raspberry plants (Table 6). Moreover, the correlations that are significant, when positive, suggest an indirect effect of the cover crops confounded with a nonsignificant nematode effect (Table 6).

Barley, a good host for the nematode, was used as the standard for comparing the effects of potential alternative cover crops. Creeping red fescue and redtop depressed raspberry cane growth, compared to barley and oat. The two grasses were chosen for this experiment because they suppressed the nematode in earlier research in apple orchards (Edwards et al., 1994). In that study and others, marigolds suppressed root-lesion nematode better than other covers, but grew too slowly and required too much handweeding to establish effectively. Freyman (1989) found that a continuous cover of white clover stimulated raspberry growth compared to barley, although these results were not confirmed in our experiment. Other studies with cover crops in raspberry have demonstrated competition and lower yields from perennial ryegrass (Chamberlain and Crandall, 1979), timothy (Phleum pratense L.) (Sanderson and Cutcliffe, 1988), and other grasses (Catzeflis et al., 1987). Since mos plantings of raspberry are infested with the root-lesion nematode, it is possible that a nematode effect was not accounted for in some of the earlier studies.

Many weeds are good hosts of the rootlesion nematode (Townshend and Davidson, 1960). In this experiment, the root systems of various weeds growing in the control plots supported many nematodes, but without any apparent effect on the nematode density in the roots or vigor of adjacent raspberry plants. The mass, diameter and number of canes was higher in the control plots than in the creeping red fescue and redtop plots, where nematode multiplication was suppressed. There may have been a combination of effects of competition for water and nutrients from the resistant cover crops, and of nematode suppression. If so, the latter effect was weaker than the former and the net effect was that raspberry growth was not affected positively by the resistant cover crops.

This study has shown that the use of resistant cover crops had no significant effect on nematode density in roots and in the rhizosphere of adjacent raspberry plants. While it is well established that resistance to root-lesion nematode is an important factor in the choice of a cover crop to reduce the nematode population before planting, it should not necessarily be the primary factor driving the choice of cover crops planted in between rows of established raspberry.

\section{Literature Cited}

Allott, D.J. 1970. Non-cultivation, a success in 10year raspberry trial. Grower 73:35-36.

Bowen, P. and S. Freyman. 1995. Ground covers affect raspberry yield, photosynthesis, and nitrogen nutrition of primocanes. HortScience 30:238-241.

British Columbia Ministry of Agriculture, Fisheries
Table 3. Mean squares for repeated measures analyses of variance of $\log _{10}$ transformed root-lesion nematode densities, Nov. 1990 to May 1993.

\begin{tabular}{|c|c|c|c|c|c|}
\hline \multirow{2}{*}{$\begin{array}{l}\text { Source of } \\
\text { variation }\end{array}$} & \multirow[b]{2}{*}{ df } & \multicolumn{2}{|c|}{ Raspberries } & \multicolumn{2}{|c|}{ Cover crops } \\
\hline & & Soil & Roots & Soil & Roots \\
\hline Cover crop & 5 & 0.050 & 0.161 & $1.996^{* *}$ & $5.964^{* *}$ \\
\hline Block & 4 & 0.038 & 0.044 & 0.155 & 0.208 \\
\hline Error A & 20 & 0.021 & 0.164 & 0.027 & 0.116 \\
\hline Date & 6 & $1.374^{* *}$ & $1.267^{* *}$ & $0.175^{* *}$ & $0.656^{* *}$ \\
\hline Date $\times$ cover crop & 30 & 0.022 & 0.134 & $0.077^{* *}$ & $0.315^{*}$ \\
\hline Date $\times$ block & 24 & 0.019 & 0.159 & 0.026 & 0.134 \\
\hline Error B & 120 & 0.022 & 0.015 & 0.024 & 0.149 \\
\hline Epsilon $^{z}$ & & 0.553 & 0.631 & 0.629 & 0.464 \\
\hline
\end{tabular}

${ }^{2}$ Greenhouse-Geisser epsilon.

${ }^{*}, * *$ Significant at $P \leq 0.05$ or 0.01 , respectively.

Table 4. Correlations among densities ${ }^{\mathbf{z}}$ of root-lesion nematodes in spring (Apr. 1991, Mar. 1992, May 1993), and fall (Nov. 1990 through 1992).

\begin{tabular}{lccc}
\hline \hline & Raspberry roots & Cover crop soil & Cover crop roots \\
\hline Spring & & & 0.15 \\
Raspberry soil & 0.10 & 0.09 & 0.03 \\
Raspberry roots & & & $0.24^{*}$ \\
Cover crop soil & & $0.33^{* *}$ & $0.60^{* *}$ \\
Fall & $0.35^{* *}$ & 0.19 & $0.27^{*}$ \\
Raspberry soil & & & $0.38^{* * *}$ \\
Raspberry roots & & & $0.60^{* *}$ \\
Cover crop soil & &
\end{tabular}

${ }^{2}$ Transformed to $\log _{10}(\mathrm{x}+100)$.

${ }^{*, * * *}$ Significant at $P \leq 0.05$ or 0.01 , respectively $(\mathrm{df}=88)$.

Table 5. Effect of cover crops on raspberry fruiting cane count, biomass, and mean height and diameter, Mar. 1994.

\begin{tabular}{|c|c|c|c|c|c|c|}
\hline \multirow[b]{2}{*}{ Cover crop } & & \multicolumn{5}{|c|}{ Raspberry canes } \\
\hline & & $\begin{array}{l}\text { Total } \\
\text { mass }^{2} \\
(\mathrm{~g})\end{array}$ & Count $^{y}$ & $\begin{array}{c}\text { Mass } \\
(\mathrm{g})\end{array}$ & $\begin{array}{c}\mathrm{Ht} \\
(\mathrm{cm})\end{array}$ & $\begin{array}{l}\text { Diam } \\
(\mathrm{mm})\end{array}$ \\
\hline None & & 1670 & 43.6 & 38.5 & 234 & 7.2 \\
\hline Barley & & 1630 & 51.8 & 32.0 & 223 & 6.7 \\
\hline White clover & & 1100 & 40.4 & 27.2 & 205 & 6.2 \\
\hline Oats & & 1770 & 48.8 & 37.0 & 223 & 6.4 \\
\hline Red fescue & & 750 & 26.4 & 28.3 & 182 & 5.3 \\
\hline Redtop & & 820 & 30.8 & 27.9 & 199 & 5.9 \\
\hline SE & & 235 & 6.93 & 1.86 & 5.65 & 0.23 \\
\hline \multicolumn{7}{|c|}{ Analysis of variance } \\
\hline $\begin{array}{l}\text { Source of } \\
\text { variation }\end{array}$ & $\underline{\mathrm{df}}$ & & & & & \\
\hline Cover crop & 5 & $104^{*}$ & 499 & $120^{* *}$ & $1837^{* * *}$ & $2.00^{* *}$ \\
\hline Block & 4 & 32 & 382 & 41 & 161 & $1.42^{* *}$ \\
\hline Error & 20 & 28 & 240 & 17 & 160 & 0.25 \\
\hline
\end{tabular}

${ }^{2}$ Total mass of canes per plot.

${ }^{y}$ Number of canes per plot.

${ }^{x}$ Values in this column are to be multiplied by $10^{4}$ to give correct total weight mean squares.

*,** Significant at $P \leq 0.05$ or 0.01 , respectively.

Table 6. Correlations between densities of root-lesion nematodes in May 1993, and raspberry fruiting cane biomass and count, and mean mass, height and diameter in Mar. 1994.

\begin{tabular}{|c|c|c|c|c|c|}
\hline \multirow[b]{2}{*}{ Location } & \multicolumn{5}{|c|}{ Nematode density ${ }^{z}$} \\
\hline & $\begin{array}{l}\text { Total } \\
\text { mass }^{\mathrm{z}} \\
(\mathrm{g})\end{array}$ & Count $^{\mathrm{y}}$ & $\begin{array}{c}\text { Mass } \\
(\mathrm{g})\end{array}$ & $\begin{array}{c}\mathrm{Ht} \\
(\mathrm{cm})\end{array}$ & $\begin{array}{l}\text { Diam } \\
(\mathrm{mm})\end{array}$ \\
\hline Raspberry soil & -0.12 & 0.22 & 0.24 & -0.01 & -0.16 \\
\hline roots & 0.25 & 0.26 & 0.12 & $0.42^{*}$ & $0.47^{* *}$ \\
\hline Cover crop soil & 0.17 & 0.21 & 0.03 & 0.24 & 0.20 \\
\hline roots & $0.51^{* *}$ & $0.49^{* *}$ & 0.25 & $0.48^{* *}$ & $0.38^{*}$ \\
\hline
\end{tabular}

${ }^{2}$ Transformed to $\log _{10}(\mathrm{x}+100)$

*,**Significant at $P \leq 0.05$ or 0.01 , respectively $(\mathrm{df}=28)$. 
and Food. 1992. Berry production guide. Victoria, B.C., Canada. p. 41-50.

Catzeflis, J., R. Terrettaz, and R. Carron. 1987. Technique culturale du framboisier. III. Deuxième essai d'entretien du sol. Revue Suisse de Viticulture, d'Arboriculture et d'Horticulture 19:373-375.

Chamberlain, J.D. and P.C. Crandall. 1979. Permanent cover crop studies in red raspberries. Proceedings Western Washington Horticultural Association. 69:142-144.

Crandall, P.C. 1980. Twenty years of red raspberry research in southwestern Washington State. Acta Hort. 112:53-58.

Crandall, P.C., J.D. Chamberlain, and K.A. Biderhost. 1974. Cane characteristics associated with berry number of red raspberry. J. Amer. Soc. Hort. Sci. 99:370-372.

Dunn, R.A. and W.F. Mai. 1973. Reproduction of Pratylenchus penetrans in roots of seven cover crop species in greenhouse experiments. Plant Dis. Rpt. 57:728-730.

Edwards, L., T.C. Vrain, and R.S. Utkhede. 1994. Effects of antagonistic plants on apple replant disease. Acta Hort. 363:135-140.

Freyman, S. 1989. Living mulch ground covers for weed control between raspberry rows. Acta Hort. 262:349-356.

Ingham, R.E. and D. Kaufman. 1992. The potential of cover crops and soil amendments for suppression of root-lesion nematodes (Pratylenchus penetrans) in small fruits. Proc. Oregon Hort. Soc. 83:194-195.

Kaufman, D. 1995. Killer mulches for nematode and weed control. Proc. Lower Mainland Horticultural Improvement Association of British Columbia 37:31-33.

Littell, R.C. 1989. Statistical analysis of experiments with repeated measures. HortScience 24:37-40.

MacDonald, D.H. and W.F. Mai. 1963. Suitability of various cover crops as hosts for the rootlesion nematode, Pratylenchus penetrans. Phytopathology 53:730-731.

Marks, C.F. and J.L. Townshend. 1973. Multiplication of the root-lesion nematode Pratylenchus penetrans under orchard cover crops. Can. J. Plant Sci. 53:187-188.

McElroy, F.D. 1972. Nematodes of tree fruits and small fruits, p. 335-376. In: J.M. Webster (ed.). Economic nematology. Academic, London.

McElroy, F.D. 1977. Effect of two nematode species on establishment, growth, and yield of raspberry. Plant Dis. Rpt. 61:277-279.

Merwin, I.A. and W.A. Stiles. 1989. Root-lesion nematodes, potassium deficiency, and prior cover crops as factors in apple replant disease. J. Amer. Soc. Hort. Sci. 114:724-728.

Powlowski, R. 1991. An investigation into cultural control of the root-lesion nematode, Pratylenchus penetrans Filipjev \& Sch. Stekoven, with special reference to apple replant disease. MS Thesis, Simon Fraser Univ., Burnaby, B.C., Canada.

Proctor, J.R. and C.F. Marks. 1974. The determination of normalizing transformations for nematode count data from soil samples and of efficient sampling schemes. Nematologica 20:395406.
Sanderson, K.R. and J.A. Cutcliffe. 1988. Effect of inter-row soil management on growth and yield of red raspberry. Can. J. Plant Sci. 68:283-285.

Seinhorst, J.W. 1956. The quantitative extraction of nematodes from soil. Nematologica 1:249-267.

Townshend, J.L. 1963. A modification and evaluation of the apparatus for the Oostenbrink direct cotton wool/ filter extraction method. Nematologica 9:106-110.

Townshend, J.L. 1989. Population densities of four species of root-lesion nematodes (Pratylenchus) in the oat cultivars, Saia and OAC Woodstock. Can. J. Plant Sci. 69:903-905.

Townshend, J.L., R.A. Cline, V.A. Dirks, and C.F. Marks. 1984. Assessment of turfgrasses for the management of Pratylenchus penetrans and Paratylenchus projectus in orchards. Can. J. Plant Sci. 64:355-360.

Townshend, J.L. and T.R. Davidson. 1960. Some weed hosts of Pratylenchus penetrans in Premier strawberry plantations. Can. J. Bot. 38:267273.

Townshend, J.L. and J.W. Potter. 1976. Evaluation of forage legumes, grasses and cereals as hosts of forage nematodes. Nematologica 22:196201.

Vrain, T.C., T. Forge, and R.M. DeYoung. 1997. Population dynamics of Pratylenchus penetrans parasitizing raspberry. Fundamental \& Applied Nematology. (In Press.)

Vrain, T.C., J. Hall, H. Daubeny, R. DeYoung, and A. Anderson. 1994. Inheritance of resistance to root lesion nematode in red raspberry. HortScience 29:1340-1341. 